\title{
SEQUENTIAL TRIALS AND THE ENGLISH RULE
}

\author{
Jef De Mot ${ }^{*}$
}

\section{Introduction}

The allocation of trial costs and the way a trial evolves are two important issues in civil procedure. With regard to the allocation of costs, in some countries each party pays virtually all of her litigation costs herself. In the United States for example, the losing party bears the court costs but not the lawyer fees of her opponent. This rule is often called the "American rule". In other countries, the successful party at trial can recover all or at least a part of his lawyer fees from the unsuccessful party. This rule is often called the "British rule" or the "English rule". ${ }^{1}$ Concerning the way a trial evolves, a dispute often involves multiple issues. For example, it is not unusual that parties disagree about some substantive issue and also about the court's jurisdiction (over the matter or the defendant). Likewise, the plaintiff and the defendant may disagree about the liability issue and the exact amount of damages. Also, the defendant may raise a counterclaim in response to the plaintiff's claim. The law can deal with multiple issues in basically two ways. ${ }^{2}$ First, it can dictate that courts should decide all issues at the same time. In other words, courts are then obliged to let the parties litigate all issues before making any decision. This is called a "unitary trial". ${ }^{3}$ Second, the law could allow courts to let the parties litigate one issue after the other and decide on each issue after the parties have litigated it. The parties thus litigate "issue 1" after which the court makes a

\footnotetext{
${ }^{*}$ Researcher FWO (Research Foundation Flanders), University of Ghent, Center for Advanced Studies in Law and Economics. I thank Gerrit De Geest, Giuseppe Dari Mattiacci, Michael Faure and Ben Depoorter for helpful comments and suggestions. All remaining errors are of course my responsibility.

${ }^{1}$ See for example Hughes, J.W. and Snyder, E.A. (1998), 'Allocation of litigation costs: American and English rules', in Newman, P. (ed.), The New Palgrave Dictionary of Economics and the Law, London, Macmillan, 1998, p. 51-56.

${ }^{2}$ Of course, in between rules are possible.

${ }^{3}$ Landes, W., 'Sequential versus unitary trials: an economic analysis', 22 Journal of Legal Studies, 1993, p. 100.
} 
decision about "issue 1". Then, if still necessary, the parties litigate "issue 2" after which the court makes a decision about "issue 2", and so forth. This is called a "sequential trial". ${ }^{4}$ In many countries courts have wide opportunities to separate issues at trial. The Federal Rules of Civil Procedure give US courts different possibilities for sequential decision making. For example, Rule 42 states that "the court, in furtherance of convenience or to avoid prejudice, or when separate trials will be conducive to expedition and economy, may order a separate trial of any claim, cross-claim, counterclaim, or third-party claim, or of any separate issue or of any number of claims, cross-claims, counterclaims, third-party claims, or issues, always preserving inviolate the right of trial by jury as declared by the Seventh Amendment to the Constitution or as given by a statute of the United States". In the UK, according to Rule 3.1(2)e of the Civil Procedure Rules, the court may direct that part of any proceedings (such as a counterclaim) be dealt with as separate proceedings. According to Rule 3.1(2) i and $\mathrm{j}$, the court can direct a separate trial of any issue and decide the order in which issues are to be tried.

This article studies sequential litigation in conjunction with the English rule. Although the English rule has been examined rather thoroughly in the economic literature ${ }^{5}$ and sequential litigation also has received some attention ${ }^{6}$, they have never been examined together. The prior literature compares unitary litigation under the American rule with sequential litigation under the American rule. The most important results from this literature are that sequential litigation (1) Lowers the expected cost of litigation for both parties compared to a unitary trial. The intuition behind this result is simple. In a sequential trial, the parties avoid litigation on subsequent issues if the defendant wins the current issue. For example, if the defendant is not held liable, the trial ends and the parties do not have to make costs to prove the exact amount of damages; (2) Increases the plaintiff's incentive to sue and so increases the number of lawsuits. This follows straight from (1). When suing becomes cheaper, more cases will be filed; (3) Reduces the likelihood that the parties will settle out of

\footnotetext{
${ }^{4}$ Ibid., p. 100.

${ }^{5}$ For an overview, see Hughes, J.W. and Snyder, E.A. (1998), 'Allocation of litigation costs: American and English rules', in Newman, P. (ed.), The New Palgrave Dictionary of Economics and the Law, London, Macmillan, 1998, p. 51-56.; see also Katz, A.W. (2000), 'Indemnity of legal fees', in B. Bouckaert and G. De Geest (ed.), The Encyclopedia of Law and Economics, Cheltenham, Edward Elgar, p. 63-94.

${ }^{6}$ Landes, W., 'Sequential versus unitary trials : an economic analysis', 22 Journal of Legal Studies, 1993, p. 99134. For an earlier, less systematic analysis, see Schwartz, W., 'Severence - a means of minimizing the role of burden and expense in determining the outcome of litigation'. 20 Vanderbilt Law Review, 1967, p. 1197-1213. For an analysis of sequential trials with one-sided private information, see Chen, K-P., Chien, J-K. and Chu, C.Y., 'Sequential versus unitary trials with asymmetric information'. 26 Journal of Legal Studies, 1997, p. 239258.
} 
court by narrowing the range of mutually acceptable settlements. Once again, this follows straight from the cost savings discussed in (1). Since a trial becomes less costly for the plaintiff, he will ask for a higher settlement amount. And since a trial also becomes less costly for the defendant, the maximum settlement amount he's willing to give decreases. The settlement range thus gets smaller with more trials as a result; (4) Has an ambiguous effect on the settlement amount, since the expected value of the plaintiff increases and the expected loss of the defendant decreases. ${ }^{7}$

In this article, I examine the influence of sequential litigation when the loser at trial pays all the litigation costs and compare the results with (a) the situation in which litigation is unitary and the loser pays all the litigation costs and (b) the situation in which litigation is sequential and each party bears his own costs. I focus on the incentive to sue, the incentive to settle (or to litigate) and on the settlement amount. I find some interesting differences with the previous literature. First, sequential litigation does not increase the incentive to sue for all disputes under the English rule. More specifically, unlike under the American rule, under the English rule one has to make a distinction between two types of disputes for which sequential litigation is possible. In the first type, the judge litigates and decides a subsequent issue, part of plaintiff's claim, conditional on the plaintiff winning all previous issues. An example is a trial in which the parties first litigate the liability issue and then, if the plaintiff wins this issue, the damages issue. I will call this a "type I sequential trial". In the second type, the parties litigate and the judge decides the defendant's counterclaim, conditional on the plaintiff losing his own claim. I call this a "type II sequential trial". In other words, these trials concern counterclaims which the defendant can only win if the plaintiff loses his own claim. ${ }^{8}$ An example would be a counterclaim that the plaintiff has infringed a trademark when the plaintiff claims that the trademark is void. The defendant can only win his counterclaim if the judge decides that the trademark is not void. Another example is a counterclaim for damages when the defendant is convinced that the plaintiff's claim is frivolous. The defendant can only win the counterclaim if the plaintiff loses his claim. In contrast with the American rule, I find that the plaintiff's incentive to sue only increases for type I sequential trials and not for type II sequential trials. Second, I find that sequential litigation also decreases the incentive to settle under the English rule. Perhaps rather surprisingly, the decrease is larger under the American rule than under the English rule. Third, the effect of sequential litigation on the settlement amount is not ambiguous under the English rule. In contrast to the American rule, it is

\footnotetext{
${ }^{7}$ All depends on who wins most with sequential litigation.

${ }^{8}$ Note that the defendant does not necessarily win the counterclaim when the plaintiff loses his own claim.
} 
perfectly predictable whether the parties will settle for more or for less when parties litigate sequentially.

I will proceed as follows. Section 2 analyzes type I sequential trials. I make an informal and a formal analysis and compare the results with sequential litigation under the American rule. In section 3, I do the same for type II sequential trials. Section 4 concludes.

\section{Type I sequential trials}

\subsection{Assumptions}

I adopt the following assumptions: both parties are risk neutral, the plaintiff only sues if the expected value of litigating his claim is positive, to file and settle a lawsuit is costless, the parties know whether a trial will be sequential, the party's litigation expenditures are fixed, the parties may have different expectations about the probability of prevailing and there are no 'diseconomies of scope' from separating issues at trial. ${ }^{9}$ Furthermore, I will only examine situations in which the parties expect to litigate (not settle) issue ' 2 ' in a sequential trial and do not settle part of the claim in a unitary trial. ${ }^{10}$ Next, the parties do not have different information (no asymmetric information). Also, the timing (sequence) of litigating the several issues is fixed. Finally, I study the "pure English rule". Under such a rule, the loser at trial (1) bears all the trial costs of the winning party and (2) bears all the trial costs, even if he wins one or more issues (but still loses the claim).

\subsection{Informal analysis}

For type I trials, sequential litigation under the English rule increases the expected value for the plaintiff and thus his incentive to sue. The defendant's expected loss however remains the

\footnotetext{
${ }^{9}$ For example: if litigating issue ' 1 ' and issue ' 2 ' in separate stages costs $1000 \$$, it costs $2000 \$$ to litigate them together.

${ }^{10}$ The reason is that there is no real difference between a unitary and a sequential trial otherwise. Landes (1993) examines bifurcated trials and distinguishes between three situations: (1) the parties agree on damages in both a unitary and a sequential trial, (2) the parties expect to litigate damages in a bifurcated trial (conditional on the plaintiff winning liability) but stipulate to damages in a unitary trial and (3) the parties expect to litigate damages in both a bifurcated (conditional on the plaintiff winning liability) and unitary trial. For the first category, there is no systematic difference between a bifurcated and a unitary trial. Landes (1993) also shows that the second category probably accounts for only a small fraction of disputes.
} 
same. The intuition is as follows. Suppose the plaintiff's claim involves two issues. ${ }^{11} \mathrm{~A}$ sequential trial may save the costs of litigating the second issue because the plaintiff can drop his claim when he loses the first issue. If the plaintiff loses the first issue, he avoids paying all the trial costs of the second issue, given that the loser pays all. On the contrary, the defendant is indifferent between a unitary and a sequential trial. If the plaintiff loses the first issue, the plaintiff will lose the trial and not only pay his own trial costs but also those of the defendant, just like in a unitary trial. ${ }^{12}$ So litigating sequentially does not advantage the defendant compared to a unitary trial. The advantage is completely concentrated on the side of the plaintiff, since he is the one that bears all the costs when he loses the first issue.

From the discussion above it is straightforward to see how a sequential trial will influence the settlement frequency and the settlement amount. Compared to a unitary trial, the plaintiff wants to receive a higher settlement amount but the defendant is not willing to give anything extra. The scope for settlement thus reduces. The influence on the settlement amount is unambiguous: it increases because sequential litigation only benefits the plaintiff.

UNITARY TRIAL

TYPE I SEQUENTIAL TRIAL

STAGE 1+STAGE 2

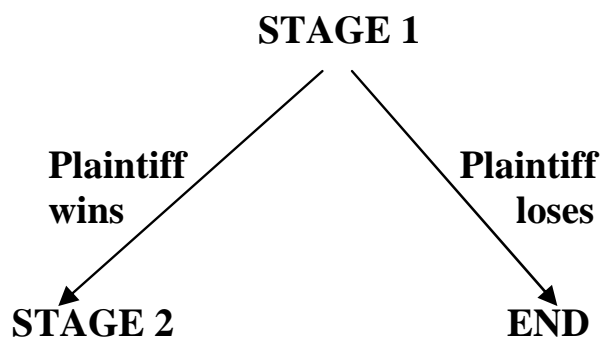

\footnotetext{
${ }^{11}$ He needs to win both issues to win the trial.

${ }^{12}$ When the plaintiff wins the first issue, the parties go on to litigate the second issue in a sequential trial as well as in a unitary trial. By assumption the parties do not settle the second issue (see above).
} 


\subsection{Formal analysis}

I will use the following notations:

pa, pb: plaintiff's and defendant's estimates of probability of plaintiff winning issue ' 1 ' qa, qb: plaintiff's and defendant's estimates of probability of plaintiff winning issue ' 2 ' $\mathrm{J}:$ the damage award if the plaintiff wins both issues

a1, b1: plaintiff's and defendant's cost of trial for issue ' 1 ' a2, b2 : plaintiff's and defendant's cost of trial for issue ' 2 '

$\mathrm{Va}, \mathrm{Vb}$ : plaintiff's and defendant's estimates of expected value of litigation in a sequential trial

$\mathrm{Va}(\mathrm{u}), \mathrm{Vb}(\mathrm{u})$ : plaintiff's and defendant's estimates of expected value of litigation in a unitary trial in which issue ' 1 ' and issue ' 2 ' are litigated together

In a sequential trial, A will sue if ${ }^{13}$

$$
\mathrm{Va}=\text { paqa } \mathrm{J}-\mathrm{pa}(1-\mathrm{qa})(\mathrm{a} 1+\mathrm{b} 1+\mathrm{a} 2+\mathrm{b} 2)-(1-\mathrm{pa})(\mathrm{a} 1+\mathrm{b} 1) \geq 0
$$

If the plaintiff wins the first issue of his claim, the parties will litigate the second issue as well (see the assumptions). If the plaintiff wins the second issue as well, he wins the claim, gets the award of $\mathrm{J}$ and bears no trial costs (loser pays). If he loses the second issue, he loses his claim, gets no award and pays all the trial costs. If the plaintiff loses the first issue, the second issue will not be litigated, but he will have to pay all the trial costs of the first issue.

B's expected loss from litigation equals

$$
\mathrm{Vb}=\operatorname{pbqb}(J+\mathrm{a} 1+\mathrm{b} 1+\mathrm{a} 2+\mathrm{b} 2)
$$

If the plaintiff wins the first issue of his claim, the parties will litigate the second issue as well (see the assumptions). If the plaintiff wins the second issue as well, he wins the claim and the defendant has to pay $\mathrm{J}$ to the plaintiff and bears all litigation costs. If the plaintiff loses the second issue after winning the first issue or loses the first issue (in which case the second issue will not be litigated), the defendant does not have to pay $\mathrm{J}$ to the plaintiff and he does not have to pay any trial costs.

\footnotetext{
${ }^{13}$ In what follows, I will not use a sign for multiplication. For example, paqa stands for pa x qa etc.
} 
The parties settle the entire lawsuit before any issue is decided if $\mathrm{Vb} \geq \mathrm{Va}$ or

$$
(\text { pbqb-paqa })(J+a 1+b 1+a 2+b 2)+a 1+b 1+p a(a 2+b 2) \geq 0
$$

In a unitary trial, A will sue if

$$
\mathrm{Va}(\mathrm{u})=\text { paqaJ }-\mathrm{pa}(1-\mathrm{qa})(\mathrm{a} 1+\mathrm{b} 1+\mathrm{a} 2+\mathrm{b} 2)-(1-\mathrm{pa})(\mathrm{a} 1+\mathrm{b} 1+\mathrm{a} 2+\mathrm{b} 2) \geq 0
$$

In a unitary trial, both issues are always litigated. If the plaintiff wins both issues, he wins his claim and gets the award J. If he wins the first issue but loses the second, or if he loses the first issue (and either wins or loses the second issue), he loses his claim, gets no award and has to pay all trial costs.

B's expected loss from litigation equals

$$
\mathrm{Vb}(\mathrm{u})=\operatorname{pbqb}(\mathrm{J}+\mathrm{a} 1+\mathrm{b} 1+\mathrm{a} 2+\mathrm{b} 2)
$$

If the plaintiff wins both issues, he wins his claim and the defendant has to pay the award $\mathrm{J}$ and all trial costs. If the plaintiff wins the first issue but loses the second, or if he loses the first issue (and either wins or loses the second issue), he loses his claim, in which case the defendant does not have to pay the award $\mathrm{J}$ and incurs no trial costs.

The parties settle the entire lawsuit before any issue is decided if $\mathrm{Vb}(\mathrm{u}) \geq \mathrm{Va}(\mathrm{u})$ or

$$
(\text { pbqb-paqa) }(J+a 1+b 1+a 2+b 2)+a 1+b 1+a 2+b 2 \geq 0
$$

The added incentive to sue for A under sequential litigation equals

$$
\mathrm{Va}-\mathrm{Va}(\mathrm{u})=(1-\mathrm{pa})(\mathrm{a} 2+\mathrm{b} 2)
$$

Sequential litigation benefits the plaintiff because he avoids the trial costs of the second issue (his own and those of the defendant) when he loses the first issue.

B's expected loss remains the same under sequential litigation:

$$
\mathrm{Vb}-\mathrm{Vb}(\mathrm{u})=0
$$

Sequential litigation does not benefit the defendant. When the plaintiff loses the first issue in a unitary trial, the defendant does not have to pay any trial costs connected to the second issue.

Sequential litigation decreases the settlement range with

$$
\mathrm{Vb}-\mathrm{Va}-(\mathrm{Vb}(\mathrm{u})-\mathrm{Va}(\mathrm{u}))=(\mathrm{Vb}-\mathrm{Vb}(\mathrm{u}))-(\mathrm{Va}-\mathrm{Va}(\mathrm{u}))=-(1-\mathrm{pa})(\mathrm{a} 2+\mathrm{b} 2)
$$


Sequential litigation increases the plaintiff's minimum settlement demand and does not influence the defendant's maximum settlement offer. This narrows down the settlement range. The settlement amount must increase since the plaintiff expects to save costs but the defendant does not.

\subsection{Comparison with sequential litigation under the American rule}

Under the American rule, both parties can save costs when they litigate sequentially. If the plaintiff loses the first issue, each party escapes bearing the trial costs of the second issue. Under the English rule, only the plaintiff saves costs. If he loses the first issue, he escapes bearing all the trial costs of the second issue because he will drop his claim after the first issue has been litigated. The defendant saves no costs because the plaintiff bears all the costs if he loses the first issue. As a consequence, the plaintiff's incentive to sue increases under both the American and the English rule, but the increase is higher under the English rule. ${ }^{14}$

The settlement range decreases under both rules of cost allocation. However, the decrease of the settlement range is smaller under the English rule than under the American rule. Intuitively, under the English rule the reduction of the settlement range only depends on how the plaintiff estimates his chances of losing the first issue (and thus avoids all trial costs of the second issue). Under the American rule, the reduction depends on how each party estimates that the plaintiff will lose the first issue (and each party avoids his own trial costs of the second issue). And since we are looking at situations in which the defendant estimates the chance that the plaintiff will lose the first issue higher than the plaintiff $(1-\mathrm{pa}<1-\mathrm{pb}$ or $\mathrm{pa}>\mathrm{pb}^{15}$ ), the settlement range decreases more under the American rule. ${ }^{16}$ The fact that the settlement frequency decreases more under the American rule than under the English rule may be surprising at first. The economic theory of litigation has shown that the settlement frequency is higher under the American rule (at least when parties are risk neutral and expenditures are exogenous). ${ }^{17}$ I stress that this is still the case for sequential trials. What I have shown is that a switch from a unitary to a sequential trial decreases the settlement

\footnotetext{
${ }^{14}$ Under the American rule, the plaintiff avoids his trial costs of the second issue. Under the English rule, the plaintiff avoids his own trial costs and those of the defendant of the second issue.

${ }^{15}$ In the opposite case $(\mathrm{pa} \leq \mathrm{pb})$, the parties would normally have settled the first issue and only asked the court to decide the second issue. In that case, there would be no difference between a unitary and a sequential trial.

${ }^{16}$ The decrease under the American rule equals (1-pa)a2 + (1-pb)b2. If pa $>$ pb, then $(1-p a) a 2+(1-p b) b 2>(1-$ pa) $(\mathrm{a} 2+\mathrm{b} 2)$.

${ }_{17}$ Shavell, S., 'Suit, settlement and trial: a theoretical analysis under alternative methods for the allocation of legal costs', 11 Journal of Legal Studies, 1982, p. 55-81.
} 
frequency most under the American rule, not that a switch from the American rule to the English rule increases the settlement frequency when litigation is sequential.

While the influence of sequential litigation on the settlement amount is ambiguous under the American rule, this is not true under the English rule: it increases. The reason is that litigating sequentially saves costs for both parties under the American rule, while it only saves costs for the plaintiff under the English rule.

\section{Type I Sequential Trials}

AMERICAN RULE

STAGE 1

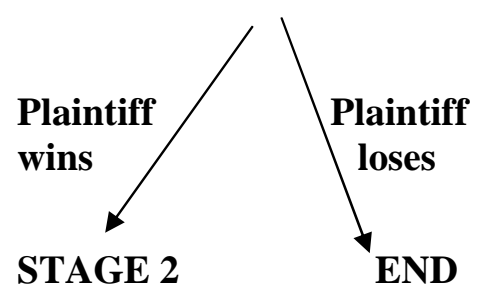

Plaintiff and defendant avoid trial costs of stage 2
ENGLISH RULE

STAGE 1

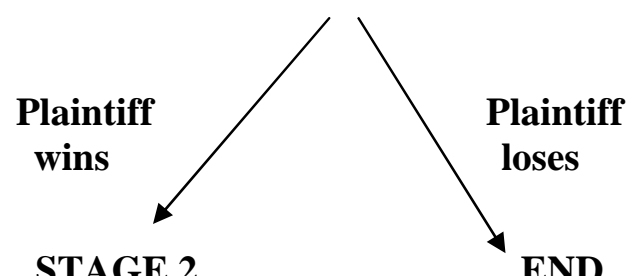

STAGE 2
Plaintiff avoids (all) trial costs of stage 2 .

\section{Type II sequential trials ${ }^{18}$}

\subsection{Assumptions}

I adopt the same assumptions as for type I sequential trials ${ }^{19}$ and add two assumptions: I focus on counterclaims which the defendant will find worthwhile to bring in a unitary as well as a

\footnotetext{
18 For a general economic analysis of counterclaims, see Landes, W., 'Counterclaims: an economic analysis', 14 International Review of Law and Economics, 1994, p. 235-244.
} 
sequential trial ${ }^{20}$ and I assume that the defendant would not file his counterclaim in a separate suit if the plaintiff would not file his claim. ${ }^{21}$

\subsection{Informal analysis}

The situation of type 2 sequential trials is the mirror image of type I sequential trials. Here, litigating sequentially has no effect on the plaintiff's expected value. The defendant's expected loss however decreases. The intuition is as follows. A sequential trial may save the costs of litigating the counterclaim when the plaintiff wins his claim because the defendant can drop his counterclaim in that case (he can not win by definition). ${ }^{22}$ If the plaintiff wins his claim and the defendant drops his counterclaim, the defendant avoids paying all the trial costs of the counterclaim (given that the loser pays all). On the contrary, the plaintiff is indifferent between a unitary and a sequential trial. If the plaintiff wins his claim, the defendant will lose the counterclaim and pay all the trial costs associated with the counterclaim, just like in a unitary trial. So litigating sequentially does not advantage the plaintiff. The advantage is completely situated on the defendant's side, since he is the one that bears all the costs of the counterclaim when the plaintiff wins his own claim.

From the discussion above, it is straightforward to see how sequential litigation will influence the settlement frequency and the settlement amount. Compared to a unitary trial, the minimum offer the plaintiff wants to receive remains the same but the maximum offer the defendant is willing to give decreases. The scope for settlement thus reduces. The influence on the settlement amount is unambiguous: it decreases since sequential litigation only benefits the defendant.

\footnotetext{
${ }^{19}$ Two of these assumptions need to be adjusted to the context of counterclaims: the defendant only counterclaims if the expected value of his counterclaim is positive and the parties expect to litigate (not settle) the counterclaim in a sequential trial and do not settle the counterclaim in a unitary trial. Once again, the reason in that otherwise there is no real difference between a unitary and a sequential trial.

${ }^{20}$ Of course, some counterclaims are filed in a sequential trial but not in a unitary trial (because in a sequential trial the defendant has more information about his chances of success after the plaintiff's claim has been litigated). In such a case, sequential litigation can obviously decrease the plaintiff's incentive to sue (since the defendant only counterclaims if litigation is sequential; the counterclaim reduces the plaintiff's expected value). ${ }^{21}$ This is done merely for the sake of mathematical simplicity. Dropping this assumption would not change the results fundamentally.

${ }^{22}$ When the plaintiff loses his claim, the parties go on to litigate the counterclaim in a sequential trial as well as in a unitary trial. By assumption the parties do not settle the counterclaim in a sequential trial.
} 
UNITARY TRIAL

STAGE 1+STAGE2

\section{STAGE 1}

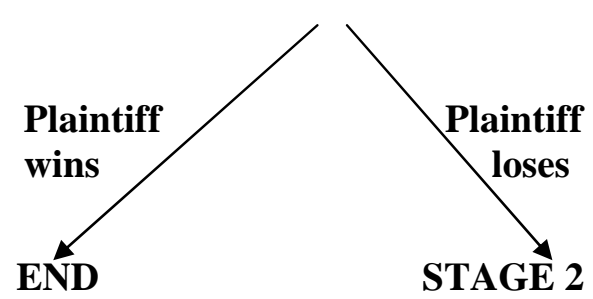

\subsection{Formal analysis}

I will use the following notations:

paqa, pbqb: plaintiff's and defendant's estimates of probability of plaintiff winning his claim ${ }^{23}$ 24

(1-pa)ra, (1-pb)rb : plaintiff's and defendant's estimates of probability of defendant winning his counterclaim

$\mathrm{J}$ : the damage award if the plaintiff wins his claim

$\mathrm{K}$ : the damage award if the defendant wins his counterclaim

a1, b1: plaintiff's and defendant's cost of trial for the plaintiff's claim

a2, b2: plaintiff's and defendant's cost of trial for the defendant's counterclaim if the counterclaim is tried in a sequential trial

\footnotetext{
${ }^{23}$ Once again, paqa stands for pa $\mathrm{x}$ qa.

${ }^{24}$ I have chosen to divide the claim and the counterclaim into two issues to model the fact that the defendant can only win his counterclaim when the plaintiff loses his claim. Although claim and counterclaim each contain two issues, I assume these two issues are litigated in a unitary trial. This is done merely to focus on the separation of claim and counterclaim instead of separating issues of respectively claim and counterclaim. The consequences of separating issues from claim (and counterclaim) follow directly from the analysis of type I sequential trials. Further, I have divided claim and counterclaim into only two issues for reasons of simplicity (any number of issues is possible).
} 
a, b : plaintiff's and defendant's cost of trial when claim and counterclaim are tried together in a unitary trial $(a=a 1+b 1, b=b 1+b 2)$

$\mathrm{Va}, \mathrm{Vb}$ : plaintiff's and defendant's estimates of expected value of litigation in a sequential trial

$\mathrm{Va}(\mathrm{u}), \mathrm{Vb}(\mathrm{u})$ : plaintiff's and defendant's estimates of expected value of litigation in a unitary trial.

In a sequential trial A will sue if

$$
\mathrm{Va}=\text { paqaJ-pa(1-qa)(a1+b1)-(1-pa)ra(K+a1+a2+b1+b2)-(1-pa)(1-ra)(a1+b1) } \geq 0
$$

If A wins both issues of his claim, he gets an award J, will not have to pay $\mathrm{K}$ (the defendant will not counterclaim because he knows he will lose) and pays no trial costs. If he wins the first issue of his claim but loses the second issue, he loses his claim, gets no award J, does not have to pay K (since the defendant will not file the counterclaim) and pays all trial costs of his claim. If he loses the first issue, he can not win his own claim and the defendant will win his counterclaim with probability ra, in which case the plaintiff has to pay the amount of $\mathrm{K}$ and all trial costs for claim and counterclaim, and will lose his counterclaim with probability 1-ra, in which case the plaintiff only incurs all trial costs for his claim.

B's expected loss from litigation equals

$$
\mathrm{Vb}=\operatorname{pbqb}(\mathrm{J}+\mathrm{a} 1+\mathrm{b} 1)-(1-\mathrm{pb}) \mathrm{rbK}+(1-\mathrm{pb})(1-\mathrm{rb})(\mathrm{a} 2+\mathrm{b} 2)
$$

If $\mathrm{A}$ wins both issues of his claim, the defendant has to pay $\mathrm{J}$ to the plaintiff, does not get $\mathrm{K}$ from the plaintiff (he will not file the counterclaim) and has to pay all trial costs of the claim. If the plaintiff wins the first issue of his claim but loses the second issue, he loses his claim and the defendant will not counterclaim, so the defendant incurs no costs. If the plaintiff loses the first issue, the defendant will not have to pay $\mathrm{J}$ to the plaintiff and the defendant will win his counterclaim with probability $\mathrm{rb}$, in which case he gets $\mathrm{K}$ from the plaintiff and incurs no trial costs, and will lose his counterclaim with probability 1-rb, in which case he has to pay all trial costs of his counterclaim.

In a unitary trial, A will sue if

$$
\mathrm{Va}(\mathrm{u})=\text { paqaJ-pa(1-qa) }(\mathrm{a} 1+\mathrm{b} 1)-(1-\mathrm{pa}) \mathrm{ra}(\mathrm{K}+\mathrm{a} 1+\mathrm{a} 2+\mathrm{b} 1+\mathrm{b} 2)-(1-\mathrm{pa})(1-\mathrm{ra})(\mathrm{a} 1+\mathrm{b} 1) \geq 0
$$

In a unitary trial, both parties always incur the costs of claim and counterclaim. If A wins both issues of his claim, he gets awarded $\mathrm{J}$, will not have to pay $\mathrm{K}$ and pays no trial costs. If 
he wins the first issue of his claim but loses the second issue, he loses his claim, gets no award $\mathrm{J}$, does not have to pay $\mathrm{K}$ (since the defendant will lose the counterclaim) and pays all trial costs of his claim. If he loses the first issue, he can not win his own claim and the defendant will win his counterclaim with probability ra, in which case the plaintiff has to pay the amount of $\mathrm{K}$ and all trial costs of claim and counterclaim, and will lose his counterclaim with probability 1-ra, in which case the plaintiff only incurs all trial costs of his claim.

B's expected value equals

$$
\mathrm{Vb}(\mathrm{u})=\operatorname{pbqb}(\mathrm{J}+\mathrm{a} 1+\mathrm{a} 2+\mathrm{b} 1+\mathrm{b} 2)+\mathrm{pb}(1-\mathrm{qb})(\mathrm{a} 2+\mathrm{b} 2)-(1-\mathrm{pb}) \mathrm{rbK}+(1-\mathrm{pb})(1-\mathrm{rb})(\mathrm{a} 2+\mathrm{b} 2)
$$

If A wins both issues of his claim, the defendant has to pay $\mathrm{J}$ to the plaintiff, does not get $\mathrm{K}$ from the plaintiff (he will not win the counterclaim) and has to pay all trial costs of claim and counterclaim. If the plaintiff wins the first issue of his claim but loses the second issue, he loses his claim and the defendant loses the counterclaim, so the defendant only incurs all trial costs of the counterclaim. If the plaintiff loses the first issue, the defendant will not have to pay $\mathrm{J}$ to the plaintiff and the defendant will win his counterclaim with probability $\mathrm{rb}$, in which case he gets $\mathrm{K}$ from the plaintiff and incurs no trial costs, and will lose his counterclaim with probability 1-rb, in which case he has to pay all trial costs of his counterclaim.

A's incentive to sue under sequential litigation remains the same :

$$
\mathrm{Va}=\mathrm{Va}(\mathrm{u})
$$

Indeed, the plaintiff does not benefit from litigating sequentially. When he wins his claim in a unitary trial, the defendant will not win the counterclaim, and the plaintiff will be compensated for his litigation costs of the counterclaim.

The increase of B's expected loss equals

$$
\mathrm{Vb}-\mathrm{Vb}(\mathrm{u})=-\mathrm{pb}(\mathrm{a} 2+\mathrm{b} 2)
$$

Litigating sequentially is beneficial for the defendant. In the plaintiff wins his claim, the defendant escapes having to pay all trial costs of the counterclaim in a sequential trial, because he can drop the counterclaim after the plaintiff wins his own claim.

Sequential litigation decreases the settlement range with

$$
\mathrm{Vb}-\mathrm{Va}-(\mathrm{Vb}(\mathrm{u})-\mathrm{Va}(\mathrm{u}))=(\mathrm{Vb}-\mathrm{Vb}(\mathrm{u}))-(\mathrm{Va}-\mathrm{Va}(\mathrm{u}))=-\mathrm{pb}(\mathrm{a} 2+\mathrm{b} 2)
$$

Since the plaintiff's minimum settlement demand remains the same and the defendant's maximum settlement offer decreases, the settlement range decreases. 
The settlement amount decreases because the defendant saves costs by litigating sequentially but the plaintiff's costs remain unaffected.

\subsection{Comparison with sequential litigation under the American rule}

Under the American rule, both parties can save costs when they litigate sequentially. If the plaintiff wins his claim, both parties escape bearing the trial costs of the counterclaim (the defendant will drop the counterclaim). Under the English rule, only the defendant can save costs. If the plaintiff wins his claim, the defendant escapes bearing all the trial costs of the counterclaim because he will drop the counterclaim. The plaintiff saves no costs because the defendant bears all the costs of the counterclaim if the plaintiff wins his claim. Consequently, the plaintiff's incentive to sue increases under the American rule but not under the English rule.

The settlement range decreases under both rules of cost allocation. The decrease of the settlement range is greater under the American rule than under the English rule. Intuitively, under the English rule the reduction of the settlement range only depends on estimation of the defendant that the plaintiff will win the issue that claim and counterclaim have in common. Under the American rule, the reduction depends on how each party estimates that the plaintiff will win the common issue. And since we focus on the situation in which the defendant's estimation that the plaintiff will lose the common issue is greater than the plaintiff's estimation $\left(\mathrm{pa}>\mathrm{pb}^{25}\right)$, the settlement range decreases more under the American rule. ${ }^{26}$

While the influence on the settlement amount is ambiguous under the American rule, this is not true under the English rule: it decreases. The reason is that litigating sequentially saves costs for both parties under the American rule, while it only saves costs for the defendant under the English rule.

\footnotetext{
${ }^{25}$ If $\mathrm{pa} \leq \mathrm{pb}$, the parties would have settled the common issue. In that case, there is no difference between a unitary and a sequential trial.

${ }^{26}$ The decrease under the American rule equals paa $2+$ pbb2. If $\mathrm{pa}>\mathrm{pb}$, then paa $2+\mathrm{pbb} 2>\mathrm{pb}(\mathrm{a} 2+\mathrm{b} 2)$.
} 
AMERICAN RULE

STAGE 1

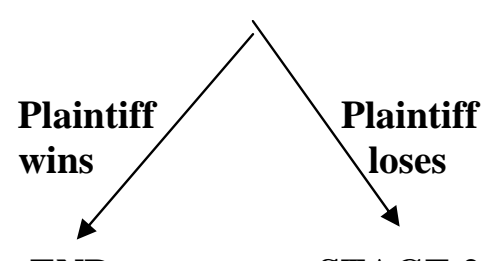

END
STAGE 2
Plaintiff and defendant avoid trial costs stage 2

\section{ENGLISH RULE}

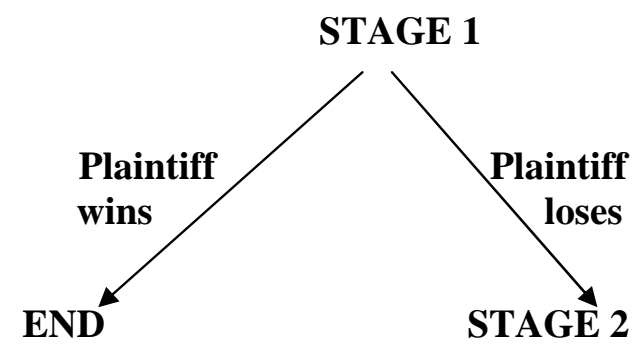

Defendant avoids

trial costs stage 2

\section{Conclusion}

The effect of litigating sequentially is less uniform under the English rule than under the American rule. Under the American rule, both parties benefit from sequential litigation. Under the English rule only one party benefits. Which party this is depends on the type of dispute (Type 1 or Type 2). Consequently, the effect of sequential litigation on the total costs of litigation may differ sharply for both types of trial. For type 1 trials, sequential litigation reduces the litigation costs of individual cases, since stage 2 is not always litigated. On the other hand, the total litigation costs of the judicial system may still increase since the incentive to sue increases and the incentive to settle decreases. For type 2 trials, sequential litigation also reduces the costs of individual cases, but does not increase the incentive to sue (although it still reduces the incentive to settle). So from a social cost perspective, sequential litigation may be more recommendable for type 2 trials than for type 1 trials under the English rule. 